\title{
DIDACTICS: PECULIARITIES OF PROGRAMMED TEACHING OF THE CARTWHEEL TO GIRLS AGED 14
}

\author{
Mykhailo Kharkovshchenko ${ }^{1 \mathrm{ABCD}}$ \\ ${ }^{1}$ Kharkiv Comprehensive School of I-III Degrees № 164 of Kharkiv City Council of Kharkiv Region \\ Authors' Contribution: A - Study design; B - Data collection; C - Statistical analysis; D - Manuscript Preparation; E - Funds Collection
}

DOI: $10.17309 / \mathrm{jltm} .2022 .1 .01$

\begin{abstract}
The purpose of the study was to determine the peculiarities of programmed teaching of the cartwheel to girls aged 14 . Materials and methods. The study participants were 20 girls aged 14 . The children and their parents were fully informed about all the features of the study and gave their consent to participate in the experiment. To solve the tasks set, the following research methods were used: study and analysis of scientific and methodological literature; pedagogical observation, timing of training tasks; pedagogical experiment, methods of mathematical statistics, factor analysis, nearest neighbor analysis.

Results. The analysis of the effectiveness of the program of teaching girls aged 14 the cartwheel, using different repetition modes ( 1 - mode of 6 sets 1 time each with a rest interval of $60 \mathrm{~s} ; 2$ - mode of 6 sets 2 times each with a rest interval of $60 \mathrm{~s}$ ) showed that the girls of the first group need fewer repetitions to master the cartwheel than the girls of the second group $(\mathrm{p}<0.05)$. Thus, repetition modes have statistically significantly different effects on the cartwheel motor skill development in girls aged 14 . The analysis of similarities revealed that the program components are interrelated.

Conclusions. Factor analysis showed that teaching programs organized by the method of algorithmic instructions are combined in nature. The analysis of similarities revealed that the program components are interrelated. Series of training tasks 2, 3, and 5 are most correlated with one another and provide conditions for teaching girls aged 14 the cartwheel. Optimization of the number of repetitions of the exercise depends on the speed of mastering the exercises of the third and fourth series of training tasks.

Keywords: programmed teaching, method of algorithmic instructions, acrobatic exercises, girls aged 14.
\end{abstract}

\section{Introduction}

The ideas of behaviorism became the methodological basis of programmed instruction (Skinner, 1965, 1984a,b; Fishman, Keller, \& Atkinson, 1968). Skinner (1965) points out that a special branch of psychology, the so-called experimental analysis of behavior, has produced a technology of teaching characterized by the introduction of teaching machines and programmed instruction. The basis of programming is the "response - stimulus" scheme. According to Skinner (1984), operant conditioning can replace, as well as complement, the natural selection of behavior.

Physical education uses the traditional scheme of a teaching program, which includes: informative frame (what is performed) - operational frame (how it is performed) control frame (transition to training the next exercise) (Shlemin, 1973; Gaverdovskii, 2007; Khudolii, 2008). In physi-

(C) Kharkovshchenko, M., 2022. cal education of schoolchildren, the method of algorithmic instructions is used to develop teaching programs (Shueva, Ivashchenko, \& Jagiello, 2021; Marchenko, \& Taranenko, 2020; Minenko, \& Marchenko, 2021).

The results of a number of studies highlight the importance of a focused approach to the process of teaching schoolchildren (Ivashchenko, Abdulkhalikova, \& Cieślicka, 2017; Ivashchenko, Berezhna, \& Cieślicka, 2020; Ivashchenko \& Sirichenko, 2020). Studies also consider the models of teaching the basic volleyball movements to primary schoolchildren (Samsudin, Setiawan, Taufik, \& Solahuddin, 2021); the patterns of developing motor competences in children and adolescents (Chan, Ha, Ng, \& Lubans, 2019; D'elia, Tortella, Sannicandro, \& D'isanto, 2020; dos Santos, Nevill, Buranarugsa, Pereira, Gomes, Reyes, Barnett, \& Maia, 2018).

Thus, it is relevant to determine the peculiarities of programmed teaching of schoolchildren.

The purpose of the study was to determine the peculiarities of programmed teaching of the cartwheel to girls aged 14 . 


\section{Materials and methods}

\section{Study participants}

The study participants were 20 girls aged 14. The children and their parents were fully informed about all the features of the study and gave their consent to participate in the experiment.

\section{Organization of the study}

To solve the tasks set, the following research methods were used: study and analysis of scientific and methodological literature; pedagogical observation, timing of training tasks; pedagogical experiment, methods of mathematical statistics, factor analysis, nearest neighbor analysis.

The pedagogical experiment examined the influence of 6 and 12 repetitions with a 60 -second rest interval during a physical education class on the number of repetitions of training tasks to the $100 \%$ level of proficiency. In the first group $(n=10)$, the girls repeated the tasks 6 sets 1 time each with a rest interval of $60 \mathrm{~s}$, in the second group $(\mathrm{n}=10)-$ 6 sets 2 times each with a rest interval of $60 \mathrm{~s}$.

During teaching, the method of algorithmic instructions was used (Shlemin, 1973). The program of teaching the cartwheel included the training tasks given in Table 1. It was developed based on the data of Shlemin (1973), Khudolii (2008). The next exercise started on condition of correct performance of the previous exercise on three consecutive attempts. The number of repetitions required for correct performance on three consecutive attempts was recorded.

\section{Statistical analysis}

The study materials were processed using the IBM SPSS 20 statistical analysis program. Factor analysis and nearest neighbor analysis were used.

The study protocol was approved by the Ethical Committee of the University. In addition, the children and their parents or legal guardians were fully informed about all the features of the study, and a signed informed consent document was obtained from all the parents.

\section{Results}

The analysis of the effectiveness of the program of teaching girls aged 14 the cartwheel, using different repetition modes ( 1 - mode of 6 sets 1 time each with a rest interval of $60 \mathrm{~s} ; 2$ - mode of 6 sets 2 times each with a rest interval of $60 \mathrm{~s}$ ) showed that the girls of the first group need fewer rep-

Table 1. Program of teaching the cartwheel to girls aged 14 (Shlemin, 1973, Khudolii, 2008)

\begin{tabular}{|c|c|c|}
\hline $\begin{array}{l}\text { Informative frame } \\
\text { (what is performed) }\end{array}$ & $\begin{array}{l}\text { Operational frame } \\
\text { (how it is performed) }\end{array}$ & $\begin{array}{l}\text { Control frame (transition to } \\
\text { training the next exercise) }\end{array}$ \\
\hline \multicolumn{3}{|c|}{ The first series of training tasks - exercises to develop motor abilities } \\
\hline $\begin{array}{l}\text { From normal standing position, lean forward, touch } \\
\text { the floor with the hands and, moving the hands } \\
\text { forward on the floor, adopt a push-up position, return } \\
\text { to starting position in the same way }\end{array}$ & $\begin{array}{l}\text { When performing the exercise, do not bend } \\
\text { the knees }\end{array}$ & $\begin{array}{l}\text { If the student performs three times } \\
\text { in } 10 \text { seconds, proceed to the next } \\
\text { exercise }\end{array}$ \\
\hline $\begin{array}{l}\text { Perform push-ups as quickly as possible ( } 5 \text { times in } \\
3-4 \mathrm{~s} \text { ) }\end{array}$ & $\begin{array}{l}\text { Perform the exercise as quickly as possible, } \\
\text { maintaining a gymnastic style }\end{array}$ & $\begin{array}{l}\text { If the student performs the } \\
\text { exercise in } 3-4 \text { seconds, proceed to } \\
\text { the next exercise }\end{array}$ \\
\hline \multicolumn{3}{|c|}{ The second series of training tasks - exercises to master starting and ending positions } \\
\hline $\begin{array}{l}\text { From standing position with raised arms, step forward } \\
\text { and perform a switch leg handstand with assistance }\end{array}$ & Switch leg handstand & $\begin{array}{l}\text { Correct performance on } 3 \\
\text { consecutive attempts }\end{array}$ \\
\hline Handstand with legs apart with assistance & $\begin{array}{l}\text { Switch leg handstand, maintaining balance } \\
\text { for } 3-4 \text { seconds }\end{array}$ & $\begin{array}{l}\text { Correct performance on } 3 \\
\text { consecutive attempts }\end{array}$ \\
\hline \multicolumn{3}{|c|}{ The third series of training tasks - actions without which it is impossible to perform the target exercise } \\
\hline $\begin{array}{l}\text { Standing on hands with legs apart with assistance, shift } \\
\text { the body weight from one hand to the other }\end{array}$ & Perform everything only with assistance & $\begin{array}{l}\text { Correct performance on } 3 \\
\text { consecutive attempts }\end{array}$ \\
\hline \multicolumn{3}{|c|}{ The fourth series of training tasks - teaching the ability to assess movements in space, by time and muscular effort } \\
\hline Arriving to handstand quickly with assistance & $\begin{array}{l}\text { Pay attention to the technique of } \\
\text { performance }\end{array}$ & $\begin{array}{l}\text { Correct performance on } 3 \\
\text { consecutive attempts }\end{array}$ \\
\hline Arriving to handstand slowly with assistance & $\begin{array}{l}\text { Pay attention to the technique of } \\
\text { performance }\end{array}$ & $\begin{array}{l}\text { Correct performance on } 3 \\
\text { consecutive attempts }\end{array}$ \\
\hline \multicolumn{3}{|c|}{ The fifth series of training tasks - preliminary exercises } \\
\hline Arriving to handstand quickly with the wall support & Maintain balance for 3-4 seconds & $\begin{array}{l}\text { Correct performance on } 3 \\
\text { consecutive attempts }\end{array}$ \\
\hline $\begin{array}{l}\text { Handstand with legs apart with 90-degree rotation } \\
\text { with assistance }\end{array}$ & $\begin{array}{l}\text { Perform all exercises for this element only } \\
\text { with assistance }\end{array}$ & $\begin{array}{l}\text { Correct performance on } 3 \\
\text { consecutive attempts }\end{array}$ \\
\hline \multicolumn{3}{|c|}{ The sixth series of training tasks - the entire exercise } \\
\hline Cartwheel with assistance & $\begin{array}{l}\text { Pay attention to the technique of } \\
\text { performance }\end{array}$ & $\begin{array}{l}\text { Correct performance on } 3 \\
\text { consecutive attempts }\end{array}$ \\
\hline Cartwheel without assistance & Maintain a gymnastic style & $\begin{array}{l}\text { Correct performance on } 3 \\
\text { consecutive attempts }\end{array}$ \\
\hline
\end{tabular}


Table 2. Analysis of the effectiveness of the program of teaching girls aged 14 the cartwheel, using different repetition modes ( 1 - mode of 6 sets 1 time each with a rest interval of $60 \mathrm{~s} ; 2$ - mode of 6 sets 2 times each with a rest interval of $60 \mathrm{~s})$

\begin{tabular}{|c|c|c|c|c|c|c|c|c|c|c|}
\hline \multirow{3}{*}{ Indicator } & \multirow{3}{*}{ modes } & \multirow{3}{*}{$\mathbf{n}$} & \multirow{3}{*}{$\mathbf{M}$} & \multirow{3}{*}{ SD } & \multicolumn{6}{|c|}{ t-test for Equality of Means } \\
\hline & & & & & \multirow[t]{2}{*}{$\mathbf{t}$} & \multirow[t]{2}{*}{$\mathbf{p}$} & \multirow[t]{2}{*}{ MD } & \multirow[t]{2}{*}{ SED } & \multicolumn{2}{|c|}{$\begin{array}{c}95 \% \text { Confidence Interval } \\
\text { of the Difference }\end{array}$} \\
\hline & & & & & & & & & Lower & Upper \\
\hline \multirow{2}{*}{$\begin{array}{l}\text { Total number of } \\
\text { repetitions }\end{array}$} & 1 & 10 & 37.9 & 3.03 & \multirow{2}{*}{8.996} & \multirow{2}{*}{0.000} & \multirow{2}{*}{-12.4} & \multirow{2}{*}{1.378} & \multirow{2}{*}{-15.295} & \multirow{2}{*}{-9.504} \\
\hline & 2 & 10 & 50.3 & 3.12 & & & & & & \\
\hline
\end{tabular}

etitions to master the cartwheel than the girls of the second group $(\mathrm{p}<0.05)$. Thus, repetition modes have statistically significantly different effects on the cartwheel motor skill development in girls aged 14 (Table 2).

\section{Structural analysis of the program of teaching \\ girls aged 14 the cartwheel (mode of 6 sets \\ 1 time each with a rest interval of $60 \mathrm{~s}$ )}

The Bartlett's test indicates the possibility of using factor analysis. The value of KMO characterizes the satisfactory adequacy of the use of factor analysis with this sample (Table 3).

Table 3. Evaluation of the Feasibility of Applying Factor Analysis

\begin{tabular}{|c|c|c|}
\hline \multicolumn{3}{|c|}{ KMO and Bartlett's Test } \\
\hline $\begin{array}{l}\text { Kaiser-Meyer } \\
\text { Adequacy (K) }\end{array}$ & sure of Sampling & 0.286 \\
\hline \multirow{3}{*}{$\begin{array}{l}\text { Bartlett's Test } \\
\text { of Sphericity }\end{array}$} & Approx. Chi-Square & 24.634 \\
\hline & Df & 15 \\
\hline & Sig. & 0.055 \\
\hline
\end{tabular}

As a result of the analysis, two factors that explain $68.035 \%$ of the variation of results were identified (Table 4 ). The first factor explains $36.184 \%$ of the variation of learning outcomes.

Table 4. Results of Factor Analysis of the Teaching Program (6 repetitions, rest interval of $60 \mathrm{~s}$ ). Rotated Component Matrix. Girls Aged 14

\begin{tabular}{lccc}
\hline \multicolumn{1}{c}{ Series of training tasks } & \multicolumn{2}{c}{ Component } & \multirow{2}{*}{$\mathbf{h}^{2}$} \\
\cline { 2 - 3 } & $\mathbf{1}$ & $\mathbf{2}$ & \\
\hline $\begin{array}{l}\text { Series I - exercises to develop motor } \\
\text { abilities }\end{array}$ & .209 & .727 & .572 \\
$\begin{array}{l}\text { Series II - exercises to master starting } \\
\text { and ending positions }\end{array}$ & -.195 & .921 & .887 \\
$\begin{array}{l}\text { Series III - actions without which it is } \\
\text { impossible to perform the target exercise }\end{array}$ & .839 & .466 & .922 \\
$\begin{array}{l}\text { Series IV - exercises to master the } \\
\text { movement control ability }\end{array}$ & .685 & -.137 & .488 \\
$\begin{array}{l}\text { Series V - preliminary exercises } \\
\text { Series VI - the entire exercise }\end{array}$ & -.570 & .624 & .714 \\
\hline & -.704 & & .499 \\
\hline
\end{tabular}

Table 5. Total Variance Explained. Girls Aged 14

\begin{tabular}{ccc}
\hline \multirow{2}{*}{ Component } & \multicolumn{2}{c}{ Rotation Sums of Squared Loadings } \\
\cline { 2 - 3 } & \% of Variance & Cumulative \% \\
\hline 1 & 36.184 & 36.184 \\
2 & 31.851 & 68.035 \\
\hline
\end{tabular}

The series that are most correlated with the factor are:

- Series 3 - actions without which it is impossible to perform the target exercise $(r=0.839)$,

- $\quad$ Series 6 - the entire exercise $(r=-0.704)$,

- Series 4 - exercises to master the movement control ability $(\mathrm{r}=0.685)$.

The factor is bipolar and indicates that optimization of the number of repetitions of the exercise depends on the speed of mastering the exercises of the third and fourth series of training tasks. The factor is interpreted as movement control.

The second factor explains $31.851 \%$ of the variation of learning outcomes.

The series that are most correlated with the factor are:

- Series 2 - exercises to master starting and ending positions $(\mathrm{r}=0.921)$,

- Series 1 - exercises to develop motor abilities $(\mathrm{r}=0.727)$,

- $\quad$ Series 5 - preliminary exercises $(r=0.624)$.

The factor can be interpreted as basic movements.

The analysis of similarities revealed that the program components are interrelated (Table 4). Series of training tasks 2,3 , and 5 are most correlated with one another and provide conditions for teaching girls aged 14 the cartwheel (Fig. 1).

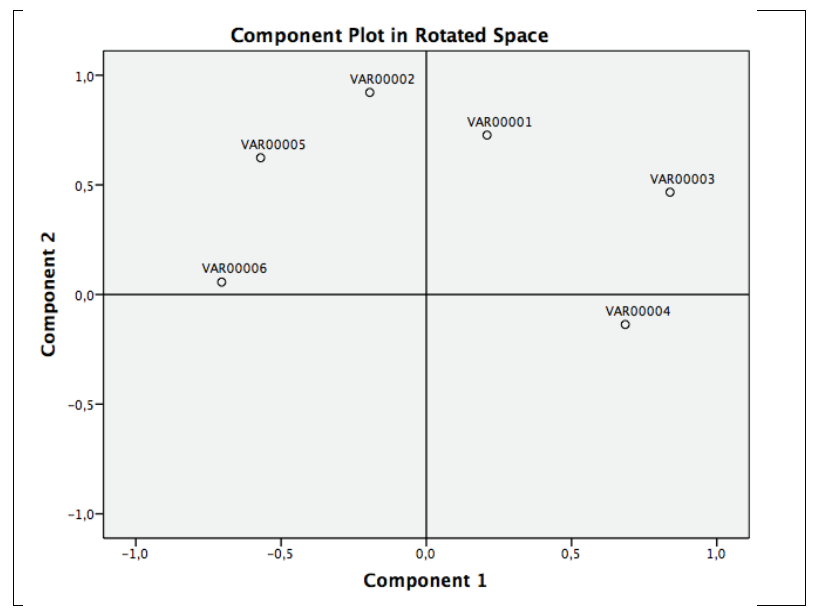

Fig. 1. Results of factor analysis of the teaching program (6 repetitions, rest interval of $60 \mathrm{~s}$ )

\section{Structural analysis of the program of teaching girls aged 14 the cartwheel (mode of 6 sets 2 times each with a rest interval of $60 \mathrm{~s}$ )}

The Bartlett's test indicates the possibility of using factor analysis. The value of KMO characterizes the satisfactory adequacy of the use of factor analysis with this sample (Table 6). 
Table 6. Evaluation of the Feasibility of Applying Factor Analysis. Girls Aged 14

\begin{tabular}{llc}
\hline \multicolumn{3}{c}{ KMO and Bartlett's Test } \\
\hline $\begin{array}{l}\text { Kaiser-Meyer-Olkin } \\
\text { Adequacy (KMO) }\end{array}$ & $\mathbf{0 . 5}$ \\
\hline \multirow{2}{*}{ Bartlett's Test of } & Approx. Chi-Square & 13.306 \\
Sphericity & Df & 15 \\
& Sig. & .579 \\
\hline
\end{tabular}

Table 7. Results of Factor Analysis of the Teaching Program (12 repetitions, rest interval of $60 \mathrm{~s}$ ). Rotated Component Matrix. Girls Aged 14

\begin{tabular}{lccc}
\hline \multicolumn{1}{c}{ Series of training tasks } & \multicolumn{2}{c}{ Component } & \multirow{2}{*}{$\mathbf{h}^{2}$} \\
\cline { 2 - 3 } & $\mathbf{1}$ & $\mathbf{2}$ & \\
\hline $\begin{array}{l}\text { Series I - exercises to develop motor } \\
\text { abilities }\end{array}$ & -.541 & .437 & .484 \\
$\begin{array}{l}\text { Series II - exercises to master starting } \\
\text { and ending positions }\end{array}$ & .813 & -.148 & .683 \\
$\begin{array}{l}\text { Series III - actions without which it } \\
\text { is impossible to perform the target }\end{array}$ & .270 & -.859 & .811 \\
$\begin{array}{l}\text { exercise } \\
\begin{array}{l}\text { Series IV - exercises to master the } \\
\text { movement control ability }\end{array}\end{array}$ & .805 & & .649 \\
$\begin{array}{l}\text { Series V - preliminary exercises } \\
\text { Series VI - the entire exercise }\end{array}$ & .597 & & .366 \\
\hline
\end{tabular}

Table 8. Total Variance Explained. Girls Aged 14

\begin{tabular}{ccc}
\hline \multirow{2}{*}{ Component } & \multicolumn{2}{c}{ Rotation Sums of Squared Loadings } \\
\cline { 2 - 3 } & \% of Variance & Cumulative \% \\
\hline 1 & 42.092 & 42.092 \\
2 & 23.241 & 65.333 \\
\hline
\end{tabular}

As a result of the analysis, two factors that explain $65.333 \%$ of the variation of results were identified (Table 7).

The first factor explains $42.092 \%$ of the variation of learning outcomes.

The series that are most correlated with the factor are:

- $\quad$ Series 2 - exercises to master starting and ending positions $(\mathrm{r}=0.813)$,

- $\quad$ Series 4 - exercises to master the movement control ability $(\mathrm{r}=0.805)$,

- $\quad$ Series 5 - preliminary exercises $(r=0.597)$.

The factor characterizes the use of the following methods: method of separate teaching (series 2), method of immediate information about the exercise performance (series 4), and method of preliminary exercises (series 5). It points to the combined nature of the teaching program.

The second factor explains $23.241 \%$ of the variation of learning outcomes.

The series that are most correlated with the factor are:

- Series 6 - the entire exercise $(r=0.960)$,

- Series 3 - actions without which it is impossible to perform the target exercise $(r=-0.859)$.

The factor can be interpreted as basic movements. The factor characterizes training tasks that are directly related to the cartwheel technique.

The analysis of similarities revealed that the program components are interrelated (Table 2). The training tasks of series 2, 4, and 5 are combined into one group and provide conditions for teaching girls aged 14 the cartwheel (Fig. 2).

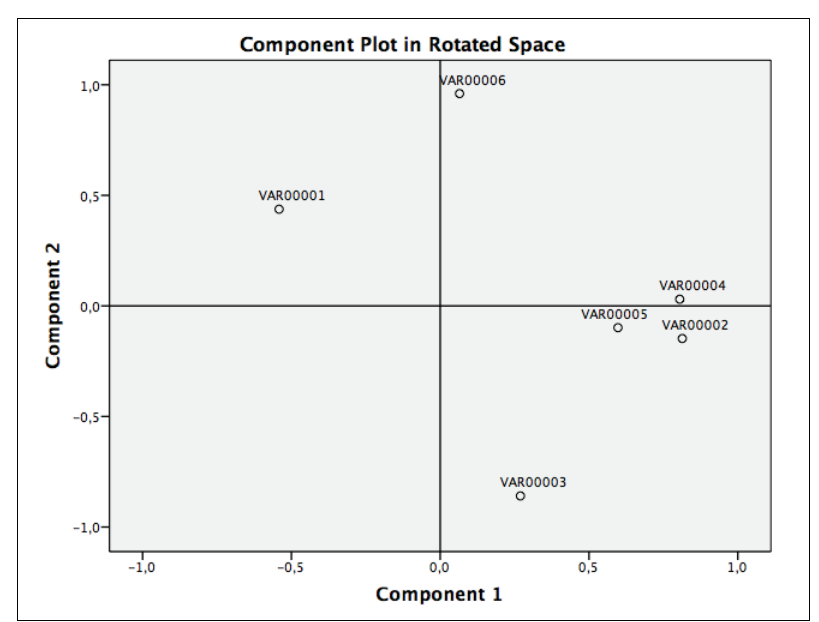

Fig. 2. Results of factor analysis of the teaching program (12 repetitions, rest interval of $60 \mathrm{~s}$ )

The analysis of implementation of the teaching program under the conditions of two exercise modes, using nearest neighbor analysis showed that the tasks of series 1,2 , and 3 are most connected with one another (Table 9, Fig. 3).

Table 9. Analysis Results. Nearest Neighbor Analysis. Girls Aged 14

\begin{tabular}{lcrc}
\hline \multicolumn{2}{c}{ Case Processing Summary } & N & Percent \\
\hline \multirow{2}{*}{ Sample } & Training & 17 & $89.5 \%$ \\
& Holdout & 2 & $10.5 \%$ \\
Valid & & 19 & $100.0 \%$ \\
Excluded & 1 & \\
Total & 20 & \\
\hline
\end{tabular}

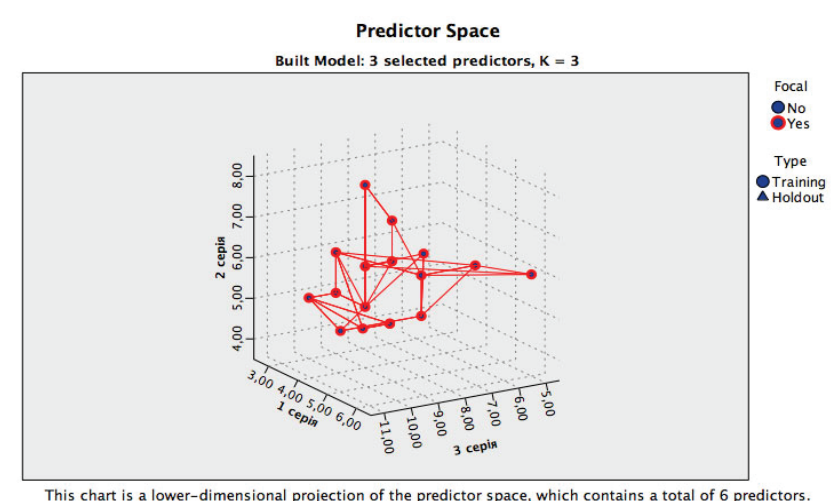

Fig. 3. Analysis Results. Nearest Neighbor Analysis. Girls Aged 14

\section{Discussion}

Thus, the assumption is made about the impact of different exercise modes on the effectiveness of teaching series of tasks. The study found that factor analysis and nearest neighbor analysis make it possible to substantiate the teaching program and identify the relationship between series of 
training tasks. Factor analysis points to the combined nature of the teaching program.

The obtained data supplement the information about the effectiveness of the method of algorithmic instructions for developing programs of teaching physical exercises to children and adolescents (Shueva, Ivashchenko, \& Jagiello, 2021; Marchenko, \& Taranenko, 2020; Minenko, \& Marchenko, 2021).

The study found that the tasks to master the movements without which it is impossible to perform the entire exercise (series 3 ) and the movement control ability (series 4) are of particular importance in the process of teaching. The data complement the findings of Shueva, Ivashchenko, and Jagiello (2021) and also confirm the combined nature of the method of algorithmic instructions (Shlemin, 1973; Khudolii, 2008; Ivashchenko, 2016).

Similarly to the research by Ivashchenko and Kapkan (2015), Shueva, Ivashchenko, \& Jagiello (2021), the study found that factor analysis and nearest neighbor analysis can be used to substantiate the teaching program, which makes it possible to identify the program structure and the relationship between each factor and the result of teaching series of training tasks.

Thus, programmed teaching such as algorithmic instructions can be considered as a technological process with a given result, which includes methods and techniques of teaching that exist in physical education and aims to develop the motor function of schoolchildren.

\section{Conclusions}

Factor analysis showed that teaching programs organized by the method of algorithmic instructions are combined in nature. The analysis of similarities revealed that the program components are interrelated. Series of training tasks 2, 3, and 5 are most correlated with one another and provide conditions for teaching girls aged 14 the cartwheel. Optimization of the number of repetitions of the exercise depends on the speed of mastering the exercises of the third and fourth series of training tasks.

\section{Acknowledgment}

The study was carried out according to the research plan of the Department of Theory and Methodology of Physical Education of H. S. Skovoroda Kharkiv National Pedagogical University within the topic "Theoretical and methodological foundations of modeling the learning process and motor abilities development in children and adolescents" (20132022) (state registration number 0112U002008).

\section{Conflict of interest}

The authors declare that there is no conflict of interest.

\section{References}

Skinner, B. F. (1965). The technology of teaching. Proceedings of the Royal Society of London. Series B, Containing papers of a Biological character. Royal Society (Great Britain), 162(989), 427-443.

https://doi.org/10.1098/rspb.1965.0048
Skinner, B. F. (1984a). Selection by consequences. Behavioral and Brain Sciences, 7(4), 477-481. https://doi.org/10.1017/S0140525X0002673X

Skinner, B. F. (1984b). Some consequences of selection. Behavioral and Brain Sciences, 7(4), 502-510. https://doi.org/10.1017/S0140525X00026984

Fishman, E. J., Keller, L., \& Atkinson, R. C. (1968). Massed versus distributed practice in computerized spelling drills. Journal of Educational Psychology, 59(4), 290-296. https://doi.org/10.1037/h0020055

Shlemin, A.M. (1973). Iunyi gimnast. M.: Fizkultura i sport, 376.

Gaverdovskii, Iu.K. (2007). Obuchenie sportivnym uprazhneniiam. Biomekhanika. Metodologiia. Didaktika. M.: Fizkultura i sport, 912.

Khudolii, O.M. (2008). Osnovy metodyky vykladannia himnastyky: Navch. posibnyk. U 2-kh tomakh. 4-e vyd., vypr. i dop. Kharkiv: «OVS», T. 1, 408.

Ivashchenko, O. (2020). Research Program: Modeling of Motor Abilities Development and Teaching of Schoolchildren. Teoriâ ta Metodika Fizičnogo Vihovannâ, 20(1), 32-41. https://doi.org/10.17309/tmfv.2020.1.05

Shueva, A., Ivashchenko, O., \& Jagiello, W. (2021). Motor Skills Development: Peculiarities of Programmed Teaching of Acrobatic Exercises to Girls Aged 15. Teoriâ ta Metodika Fizičnogo Vihovannâ, 21(4), 350-356. https://doi.org/10.17309/tmfv.2021.4.10

Marchenko, S., \& Taranenko, O. (2020). Managing the Effectiveness of Teaching Boys Aged 10 Mawashi-Geri (Roundhouse Kick) Technique in Kyokushin Karate. Teoriâ ta Metodika Fizičnogo Vihovannâ, 20(4), 262-268. https://doi.org/10.17309/tmfv.2020.4.10

Minenko, Y., \& Marchenko, S. (2021). Improvement of the Process of Teaching the Technique Boys Aged 10 Ushiro Geri Kekomi (Back Kick). Journal of Learning Theory and Methodology, 2(2), 91-97. https://doi.org/10.17309/jltm.2021.2.06

Ivashchenko, O., Berezhna, H., \& Cieślicka, M. (2020). Motor Skills in the Structure of Physical Fitness of 7-Year-Old Boys. Journal of Learning Theory and Methodology, 1(1), 14-19. https://doi.org/10.17309/jltm.2020.1.02

Ivashchenko, O., \& Sirichenko, D. (2020). Structure of Motor Fitness of 7-Year-Old Girls. Journal of Learning Theory and Methodology, 1(1), 20-25. https://doi.org/10.17309/jltm.2020.1.03

Ivashchenko, O., Abdulkhalikova, T., \& Cieślicka, M. (2017). Effectiveness of Motor Skills Development in 5th-7th Grade Girls at Different Modes of Physical Exercises. Teoriâ ta Metodika Fizičnogo Vihovannâ, 17(4), 201-207. https://doi.org/10.17309/tmfv.2017.4.1205

Samsudin, S., Setiawan, I., Taufik, M., \& Solahuddin, S. (2021). Volleyball Fundamental Movement Learning Model in Primary School. Teoriâ ta Metodika Fizičnogo Vihovannâ, 21(3), 194-199. https://doi.org/10.17309/tmfv.2021.3.02

Jufrianis, J., Henjilito, R., Hernawan, H., Sukiri, S., Sukur, A., Abidin, D., Karakauki, M., Syed Ali, S., \& Pratama, K. (2021). The Effect of Knowledge Level (IQ) and Physical Conditions (Power, Flexibility and Coordination) on Smash Technique Learning Skill in Sepak Takraw. Teoriâ 
ta Metodika Fìzičnogo Vihovannâ, 21(3), 264-272. https://doi.org/10.17309/tmfv.2021.3.10

Chan, C. H. S., Ha, A. S. C., Ng, J. Y. Y., \& Lubans, D. R. (2019). Associations between fundamental movement skill competence, physical activity and psycho-social determinants in Hong Kong Chinese children. Journal of Sports Sciences, 37(2), 229-236. https://doi.org/10.1080/02640414.2018.1490055

D’elia, F., Tortella, P., Sannicandro, I., \& D'isanto, T. (2020). Design and teaching of physical education for children and youth. Journal of Human Sport and Exercise, 15(4), S1527-S1533.

https://doi.org/10.14198/jhse.2020.15.Proc4.48 dos Santos, M. A. M., Nevill, A. M., Buranarugsa, R., Pereira, S., Gomes, T. N. Q. F., Reyes, A., Barnett, L. M., \& Maia, J. A. R. (2018). Modeling children's development in gross motor coordination reveals key modifiable determinants. An allometric approach. Scandinavian Journal of Medicine and Science in Sports, 28(5), 1594-1603. https://doi.org/10.1111/sms.13061

Ivashchenko, O. V. (2016). Modelling of physical education students. Kharkiv, OVS, 360 p.

Ivashchenko, O. V., \& Kapkan, O. O. (2015). Simulation of process of 14-15 years old girls' training of light athletic and gymnastic exercises. Pedagogics, psychology, medicalbiological problems of physical training and sports, 19(8), 32-39. https://doi.org/10.15561/18189172.2015.0805

\title{
ДИДАКТИКА: ОСОБЛИВОСТІ ПРОГРАМОВАНОГО НАВЧАННЯ ПЕРЕВОРОТУ УБІК ДІВЧАТ 14 РОКІВ
}

\author{
Михайло Харьковщенко ${ }^{1 \mathrm{ABCD}}$ \\ ${ }^{1}$ Харківська загальноосвітня школа I-III ступенів № 164 Харківської міської ради Харківської області \\ Авторський вклад: А - дизайн дослідження; В - збір даних; C - статаналіз; D - підготовка рукопису; Е - збір коштів \\ Реферат. Статья: 6 с., 9 табл., 3 рис., 21 джерело.
}

Мета дослідження - визначити особливості програмованого навчання перевороту убік дівчат 14 років.

Матеріали і методи. У дослідженні прийняли участь 20 дівчат 14 років. Діти та їхні батьки були інформовані про всі особливості дослідження і дали згоду на участь в експерименті. Для вирішення поставлених завдань були використані методи дослідження: вивчення та аналіз науково-методичної літератури; педагогічне спостереження, хронометраж навчальних завдань; педагогічний експеримент, методи математичної статистики, факторний аналіз, метод найближчих сусідів.

Результати. Аналіз ефективності програми навчання перевороту убік дівчат 14 років при різних режимах повторень (1 - режим 6 підходів по 1 разу з інтервалом відпочинку 60 c; 2 - режим 6 підходів по 2 рази з інтервалом відпочинку 60 с) показав, що дівчата першої групи витрачають менше повторень на оволодіння перевороту убік ніж дівчата другої групи $(\mathrm{p}<0,05)$. Отже режими повторень статистично достовірно мають різний вплив на формування рухової навички перевороту убік у дівчат 14 років. Аналіз спільностей дозволив встановити, що компоненти програми взаємозв'язані.

Висновки. На основі факторного аналізу встановлено, що програми навчання упорядковані за методом алгоритмічних розпоряджень мають комбінований характер. Аналіз спільностей дозволив встановити, що компоненти програми взаємозв'язані. Найбільшу кореляцію мають 2, 3 та 5 серії навчальних завдань і забезпечують умови для навчання перевороту убік дівчат 14 років. Оптимізація кількості повторень вправи залежить від швидкості засвоєння вправ третьої і четвертої серії навчальних завдань.

Ключові слова: програмоване навчання, метод алгоримічних розпоряджень, акробатичні вправи, дівчата 14 років.

\section{Information about the authors:}

Kharkovshchenko Mykhailo: mixa199710@gmail.com; https://orcid.org/0000-0003-3851-8131; Kharkiv comprehensive school of I-III degrees № 164 of Kharkiv city council of Kharkiv region, Metrobudivnykiv St, 18, Kharkiv, 61183, Ukraine.

Cite this article as: Kharkovshchenko, M. (2022). Didactics: Peculiarities of Programmed Teaching of the Cartwheel to Girls Aged 14. Journal of Learning Theory and Methodology, 3(1), 5-10. https://doi.org/10.17309/jltm.2022.1.01

Received: 25.10.2021. Accepted: 05.02.2022. Published: 28.02.2022

This work is licensed under a Creative Commons Attribution 4.0 International License (http://creativecommons.org/licenses/by/4.0). 